\title{
Estimating GHG Emission Level from Oil and Gas Offshore Production Facility
}

\author{
Satya Pinem*, Mahawan Karuniasa, and Chairil Abdini \\ School of Environmental Science, Universitas Indonesia, Salemba 4 Jakarta 10430, Indonesia
}

\begin{abstract}
Oil and gas $(\mathrm{O} \& \mathrm{G})$ production activities emits greenhouse gases (GHG) which must be well estimated to improve accountability and formulating efficient mitigation. The Indonesia's GHG emission reported thru Nationally Determined Contribution (NDC) was estimated by Tier-1 Intergovernmental Panel on Climate Change (IPCC) method, while the O\&G company adopts different methodology. This leads to asynchronous GHG emission contribution of this industry to national GHG emission. This paper aims to estimate the GHG inventory from O\&G offshore production facility by using American Petroleum Institute (API) Compendium Methodology and compare it with Tier-1 IPCC Methodology. It found that GHG emission estimated by API method is significantly lower than IPCC method. Both methods shown fuel combustion sources are the dominant. GHG emission sources from fuel combustion and flaring have been well identified, but emission sources from venting and fugitive need to be improved. Moreover this study identified that to have more accurate national GHG inventory, the GHG calculation method might be different for each industry segment. This evaluation could improve the future national GHG inventory and as reference for the industry. National emission factors database for $O \& G$ industry segment is highly suggested to be developed.
\end{abstract}

\section{Introduction}

Global warming is one of major environmental concern since it has impact on human health, ecosystems, hydrological cycle, natural resources, and the ability of organisms to live and spread $[1,2]$. The earth's temperature has increased by $0.85{ }^{\circ} \mathrm{C}$ in year $1880-2012$ and the global mean sea level has risen by 0.19 meter in year 1901-2010 [3]. The increasing of greenhouse gases (GHG) concentration in the atmosphere is the causes of this phenomena with the most contributor gases are methane $\left(\mathrm{CH}_{4}\right)$ and carbon dioxide $\left(\mathrm{CO}_{2}\right)$ [4], that is $60 \%$ and $15-18 \%$ respectively [5, 6]. Energy sector is the second largest contributor of $\mathrm{CH}_{4}$ emission which contributes $37 \%$ of the total $\mathrm{CH}_{4}$ emission, while the O\&G industry is the largest producer of $\mathrm{CH}_{4}$ emissions in the energy sector [7] Methane, the main component of natural gas, is a more potent GHG gas than $\mathrm{CO}_{2}$ as methane produces 25 times of trapped heat in the atmosphere when compared to $\mathrm{CO}_{2}$ [8]. GHG emissions from $\mathrm{O} \& \mathrm{G}$ systems are projected to increase by $26 \%$ during 2010-2030 [9]. In Indonesia, the fugitive emission

* Corresponding author: satya.dharma@ui.ac.id 
generated from oil and gas for year 2014 is $20,296 \mathrm{Gg} \mathrm{CO}_{2} \mathrm{e}$ which increased from 19,714 Gg $\mathrm{CO}_{2} \mathrm{e}$ in 2012 [10].

The current literature on GHG emissions in O\&G industry are mainly focus on emission estimation methodology [11-15] and emission reduction program [16-19]. There are significant variations in the quality and accuracy of methodologies to measure, quantify, and estimate greenhouse gas emission especially in oil and gas industry. Some authors have address this concern when use different methodologies to calculate GHG emission level in the gas pipeline [20], and GHG emission from an onshore oil and gas exploration [15]. They argue that different methodology will produce different emission estimation. A consistent and accurate methodology shall be utilized to develop an emission inventory that represent $\mathrm{O} \& \mathrm{G}$ industry segment operations [11].Goldenberg [12] proposes an activity-based emission factor to provide higher quality data. In agreement with him, Ibemere \& Mmata [14] suggest a laboratory approach to provide more precise, reliable and traceable result and reduce uncertainties. Chen et al. [15] argues that GHG emissions calculated by specific emission factor based on gas composition would technically be more acceptable. This study aims to contribute to the literature by evaluating the GHG inventory from an offshore upstream oil and gas production facility in Indonesia by using two different methodology.

The GHG emission in upstream O\&G industry generally produced from fossil fuel combustion, intentionally releasing gas to atmosphere for operational consideration (venting), gas flaring and fugitive emission from valves, flanges, connectors, pumps, compressor seal leaks, etc [8]. The reported GHG inventory from O\&G industry is important because it's related to the GHG emission that reported through Nationally Determined Contribution (NDC) document. Furthermore, GHG inventory is needed to determine the level, status, and trend of GHG emission changes on a regular basis as well as to evaluate the effectiveness of the reduction strategy [21]. The Indonesian National GHG inventory form all sector, including energy sector, which reported thru NDC was estimated by using Tier-1 IPCC methodology [10]. The publication of GHG inventory from upstream O\&G industry in Indonesia is still very limited. Special Task Force for Upstream Oil and Gas Business Activities in Indonesia (SKK Migas) reported that the inventory of GHG emission from upstream oil and gas production activities in Indonesia is still unavailable since there's still different understanding of data compilation of energy usage across Production Sharing Contractor (PSC) companies that operated in the country [22].

The purpose of this study is to evaluate the GHG emission inventory from one of upstream oil and gas production facility in Indonesia which located at offshore area. The GHG emission will be evaluated by using API method, as the adopted method in O\&G industry, and IPCC method which is using for NDC report. The greenhouse gases reported are carbon dioxide $\left(\mathrm{CO}_{2}\right)$, methane $\left(\mathrm{CH}_{4}\right)$, and nitrogen oxide $\left(\mathrm{N}_{2} \mathrm{O}\right)$ because these are the dominant greenhouse gases produced in oil and gas production operations [8].

This paper is intended to answer two questions, firstly, how the oil and gas company calculate their GHG inventory, and secondly, how much the difference of estimated GHG inventory by API and IPCC method. Answering these questions will provide more understanding of the applied GHG calculation methodology in the industry and find the gap with the IPCC methodology which use for NDC. Accurate GHG inventory is critical for establishing the fit-for-purpose mitigation program as well as improve accountability. Research result would be beneficial as reference for similar industries in estimating GHG inventory and provide improvement to the reported national GHG.

This evaluation was conducted at one of offshore oil and gas facility in Indonesia region. The production facility consist of a Well Head Platform (WHP) and a Central Processing Platform (CPP). The CPP consists of a common offshore oil and gas production facilities such as pipeline from wellhead platform and subsea wells, two-phase production separator, gas inlet separator, gas export and injection compression system, gas dew point control, gas 
dehydration system, allocation metering, export pumps, and all necessary support utilities. The simplified process flow diagram (PFD) at the CPP is presented in the Fig. 1.

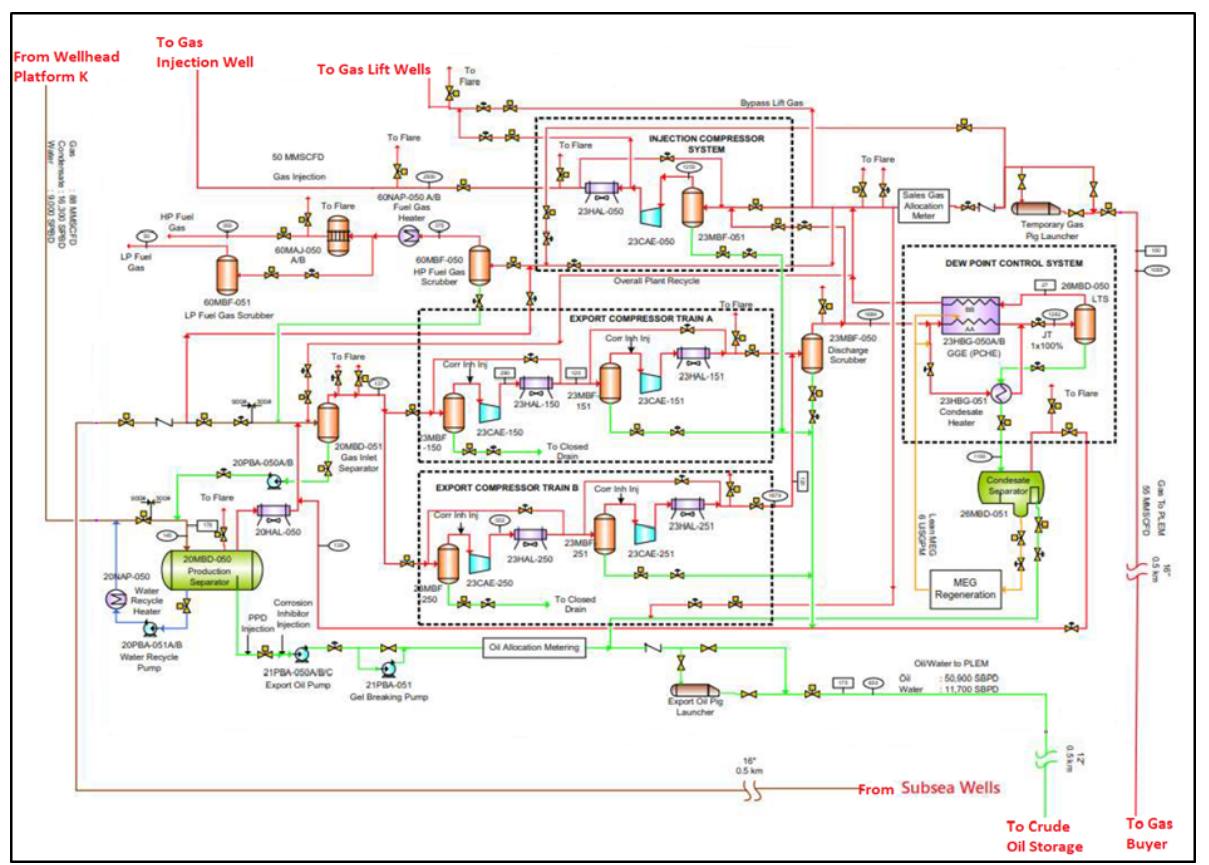

Fig. 1. Simplified PFD of oil and gas processing at Central Processing Platform

A number of process were occurred in the CPP platform, such as oil/gas separation, oil/water separation, gas dehydration, gas compression, gas dew point control, liquid pumping, gas flaring, etc. Well produces oil, water, and gas which separated in a separator. The separated gas is dehydrated to meet the sales gas specification and compressed to the required pressure and delivered to buyer thru pipeline. Literature study, plant survey, and interview with related personnel was conducted to understand the oil and gas production process in the platform as well as identifying possible sources of GHG emission. Tracing the raw data and calculation formula was also performed to understand the methodology used by company in calculating the GHG inventory. GHG emission is presented in unit ton carbon dioxide equivalent (ton $\mathrm{CO}_{2}$ eq). Emission of $\mathrm{CH}_{4}$ and $\mathrm{N}_{2} \mathrm{O}$ are converted to $\mathrm{CO}_{2}$ eq by using conversion factor namely global warming potential (GWP) which are 25 and 298 respectively for $\mathrm{CH}_{4}$ and $\mathrm{N}_{2} \mathrm{O}$ [23].

\section{Method}

\subsection{American Petroleum Institute (API) Compendium Methodology}

The petroleum industry has their GHG accounting and reporting guidance that is focused specifically on its operations. Member companies of the American Petroleum Institute (API) publish the Compendium of Greenhouse Gas Emissions Estimation Methodologies for the Oil and Gas Industry [24] or known as API Compendium Methodology which was adopted by O\&G company to estimate their GHG emission. This method basically based on field measurement data by analyse the fuel composition, emitted gas composition, and flow 
measurement of fuel consumption. According to this method, the formula to estimate GHG emission would be specific for each of emission source as shown in Table 1 [8].

Table 1. GHG estimation formula based on API Compendium Method

\begin{tabular}{|c|c|c|}
\hline GHG Emission Source & Estimating Formula & \\
\hline Gas fuel combustion & $\mathrm{E}_{\mathrm{co} 2}=\mathrm{FC} \times \mathrm{MW}_{\mathrm{sx}} \mathrm{x} \mathrm{wt} \% \mathrm{C}$ x (44/12) / 23.685 & \\
\hline Liquid fuel combustion & $\mathrm{E}_{\mathrm{c} \alpha}=\mathrm{FC} \times \mathrm{D} \times \mathrm{wt} \% \mathrm{C} \times(44 / 12)$ & \\
\hline \multirow{2}{*}{ Flaring } & $\mathrm{E}_{\mathrm{cos}}=\left[\mathrm{HC} \times \mathrm{CF}_{\mathrm{Hc}} \times(\mathrm{FE} /(1-\mathrm{FE})) \times(44 / 12)\right]+\mathrm{M}_{\mathrm{cos}}$ & (3) \\
\hline & $\mathrm{E}_{\mathrm{cH}}=\mathrm{V} \mathrm{x} \mathrm{X_{ \textrm {CH } } \times} \% \operatorname{res}_{\mathrm{cH}} \times \mathrm{MW}_{\mathrm{cH}} / 23.685$ & $(4)$ \\
\hline \multirow[t]{2}{*}{ Venting } & $\mathrm{E}_{\mathrm{cos}}=\mathrm{VR} \times \mathrm{X}_{\mathrm{co2} 2} \times \mathrm{MW}_{\mathrm{co2}}$ × VT x n / 23.685 & \\
\hline & $\mathrm{E}_{\mathrm{CH}}=\mathrm{VR} \times \mathrm{X}_{\mathrm{CH}} \times \mathrm{MW}_{\mathrm{CH}} \times \mathrm{VT} \times \mathrm{n} / 23.685$ & (6) \\
\hline Fugitive & $\mathrm{E}_{\mathrm{CH}}=\mathrm{F}_{\mathrm{A}} \times \mathrm{WF}_{\mathrm{cH}} \times \mathrm{N}$ & \\
\hline
\end{tabular}

Note:

$\mathrm{E}_{\mathrm{cos}} \quad$ emission of $\mathrm{CO}_{2}\left(\mathrm{~kg} \mathrm{CO}_{2}\right)$

$\mathrm{E}_{\mathrm{cm}} \quad$ : emission of $\mathrm{CH}_{4}\left(\mathrm{~kg} \mathrm{CH}_{4}\right)$

FC : volume of fuel consumed $\left(\mathrm{m}^{3}\right)$

$\mathrm{MW}_{\mathrm{as}}$ : molecular weight of fuel gas $(\mathrm{kg} / \mathrm{kmol})$

wt $\% \mathrm{C}$ : weight $\%$ of atom carbon (C) in gas fuel

23.685 : conversion factor of molar volume to mass $(\mathrm{m} / \mathrm{kmole})$

(44/12) : stoichiometric conversion of $\mathrm{C}$ to $\mathrm{CO}_{2}$

D : liquid fuel density $\left(\mathrm{kg} / \mathrm{m}^{3}\right)$

$\mathrm{HC} \quad$ : hydrocarbon mass emission rate from the flare $(\mathrm{kg}$ of atom $\mathrm{C})$

$\mathrm{CF}_{\text {нс }} \quad:$ weight fraction of atom $\mathrm{C}$ in hydrocarbon

FE : flare destruction efficiency, assumed $98 \%$

$\mathrm{M}_{\mathrm{co2}} \quad$ : mass of $\mathrm{CO}_{2}$ in flared stream based on $\mathrm{CO}_{2}$ composition of the stream $\left(\mathrm{kgCO}_{2}\right)$

$\mathrm{V} \quad$ : volume of gas flaring $\left(\mathrm{M}^{3}\right)$

VR : venting rate per event at standard conditions $\left(\mathrm{m}^{3} / \mathrm{min}\right)$

VT : time duration of the venting event (min)

$\%$ res $_{\mathrm{cH}}:$ non combusted fraction of flared stream, assumed $2 \%$

$\mathrm{X}_{\text {снн }} \quad:$ mol fraction of $\mathrm{CH}_{4}$ in flared or vented gas

$\mathrm{X}_{\mathrm{co2}} \quad:$ mol fraction of $\mathrm{CO}_{2}$ in flared or vented gas

$\mathrm{MW}_{\mathrm{cH}} \quad$ : molecular weight of $\mathrm{CH}_{4}(\mathrm{~kg} / \mathrm{kmol})$

$\mathrm{MW}_{\mathrm{cos}} \quad$ : molecular weight of $\mathrm{CO}_{2}(\mathrm{~kg} / \mathrm{kmol})$

$\mathrm{F}_{\mathrm{A}} \quad:$ emission factor for specific equipment leak ( $\mathrm{kg} \mathrm{CH} /$ equipment)

$\mathrm{WF}_{\mathrm{CH}}$ : mass fraction of $\mathrm{CH}_{4}$ in the equipment stream

$\mathrm{N} \quad$ : number of specific leak equipment in the production facility

$\mathrm{n} \quad$ : number of events 


\subsection{Intergovernmental Panel on Climate Change (IPCC) Guideline Methodology}

In general, GHG calculation by 2006 IPCC Guideline is based on formula that GHG emission from an emission source is the result of emission factor (EF) multiply by activity factor (AF) as presented in following equation [25]

$$
\text { Emission }=\sum_{i=1}^{\# \text { source }} E F i \times A F i
$$

where,

Emission : GHG emission (kg/year)

EFi : emission factor from emission source i (kg GHG/activity)

$\mathrm{AFi} \quad$ : activity factor from emission source i (activity/year)

The emission factor (EF) is the differentiator of GHG calculation methodology by IPCC method which known as Tier. Tier-1 uses the IPCC default emission factor, Tier-2 uses country-specific emission factors, while Tier-3 uses measurements and data at individual plant level. In this study, the emission factor to estimate the GHG emission from fugitive, flaring, and venting sources by using Tier-1 IPCC method would be the averaged value of the default one which given in the IPCC Guideline, as shown in Table 2 [25]. The activity factor for combustion sources is typically the amounts of fuels combusted while the activity factor for fugitive emission is the amount of gas released to the atmosphere thru gas flaring, venting, and equipment leaks

Table 2. Averaged default Tier-1 IPCC emission factor for fugitive, venting and flaring

\begin{tabular}{|c|c|c|c|c|}
\hline $\begin{array}{l}\text { IPCC } \\
\text { Code }\end{array}$ & Sector & \multicolumn{3}{|c|}{$\begin{array}{c}\text { Emission Factor } \\
\left(\mathbf{G g} / \mathbf{1 0} \cdot \mathrm{m}^{3} \text { production }\right)\end{array}$} \\
\hline 1.B.2 & Oil and Gas & $\mathrm{CH}_{4}$ & $\mathrm{CO}_{2}$ & $\mathrm{~N}_{2} \mathrm{O}$ \\
\hline 1.B.2.a & Crude Oil & & & \\
\hline 1.B.2.a.i & Venting & $8.55 \mathrm{E}-04$ & $1.13 \mathrm{E}-04$ & 0 \\
\hline 1.B.2.a.ii & Flaring & $2.95 \mathrm{E}-05$ & $4.85 \mathrm{E}-02$ & $7.60 \mathrm{E}-07$ \\
\hline $\begin{array}{l}\text { 1.B.2.a.i } \\
\text { ii. } 2\end{array}$ & Fugitive & $5.90 \mathrm{E}-07$ & 4.30E-08 & 0 \\
\hline 1.B.2.b & Natural Gas & & & \\
\hline 1.B.2.b.i & Venting & $1.22 \mathrm{E}-02$ & $9.70 \mathrm{E}-05$ & 0 \\
\hline 1.B.2.b.ii & Flaring & $8.80 \mathrm{E}-07$ & $1.40 \mathrm{E}-03$ & $2.50 \mathrm{E}-08$ \\
\hline
\end{tabular}

\section{Result and Discussion}

Field study identify that GHG emissions from fuel combustion mainly comes from gas turbine compressors, gas turbine generator, diesel power generator and diesel engines. Compressors are required to increase gas pressure in order to deliver sales gas to the buyers thru hundreds kilo meter of pipeline. Gas turbine generators are required to generate electric power to support production activities, while diesel fuel generator is required as the power generator during specific condition, such as plant start-up or plant shut-down or in emergency situation. There are also some equipment in the platform such as cranes and pumps that using diesel engine which also as the source of GHG emission from fuel combustion. Flaring and venting of gas occur in normal and emergency situations when pressure must be relieved from process vessels and equipment in order to avoid an unsafe condition or catastrophic failure. Fugitive emission is unintentional emissions from equipment leaks; these leaks 
generally occur through valves, flanges, seals, or related equipment associated with "live" crude or gas system components. The summary of GHG emission inventory based on API Compendium and IPCC method is presented in Table 3.

Table 3. Estimation results of GHG emission with different methodologies

\begin{tabular}{|c|c|c|c|c|c|c|c|c|}
\hline \multirow{2}{*}{$\begin{array}{l}\text { Emission } \\
\text { Source }\end{array}$} & \multicolumn{4}{|c|}{ API Compendium (ton/year) } & \multicolumn{4}{|c|}{ IPCC Guideline (ton/year) } \\
\hline & $\mathrm{CH}_{4}$ & $\mathrm{CO}_{2}$ & $\mathrm{~N}_{2} \mathrm{O}$ & $\mathrm{CO}_{2} \mathrm{e}$ & $\mathrm{CH}_{4}$ & $\mathrm{CO}_{2}$ & $\mathrm{~N}_{2} \mathrm{O}$ & $\mathrm{CO}_{2} \mathrm{e}$ \\
\hline $\begin{array}{c}\text { Fuel } \\
\text { combustion }\end{array}$ & 2.67 & $\begin{array}{l}161,32 \\
6\end{array}$ & $\begin{array}{r}0.267 \\
4\end{array}$ & $\begin{array}{l}161,47 \\
3\end{array}$ & 2.9 & $\begin{array}{l}163,20 \\
1\end{array}$ & $\begin{array}{l}0.29 \\
1\end{array}$ & $\begin{array}{l}163,36 \\
1\end{array}$ \\
\hline Flaring & $\begin{array}{l}22.1 \\
0\end{array}$ & 3,996 & $\begin{array}{r}0.609 \\
4\end{array}$ & 4,730 & $\begin{array}{l}0.28 \\
5\end{array}$ & 454 & $\begin{array}{l}0.00 \\
8\end{array}$ & 463 \\
\hline Venting & $\begin{array}{l}0.01 \\
2 \\
\end{array}$ & 0.0007 & $\begin{array}{r}0.000 \\
0 \\
\end{array}$ & 0.31 & $\begin{array}{l}0.34 \\
7 \\
\end{array}$ & 19.7 & 0 & 8.7 \\
\hline Fugitives & 0.03 & 0.0000 & $\begin{array}{r}0.000 \\
0\end{array}$ & 0.80 & $\begin{array}{l}3,78 \\
0\end{array}$ & 30.1 & 0 & 94,534 \\
\hline $\begin{array}{c}\text { Total GHG } \\
\text { emission }\end{array}$ & $\begin{array}{l}24.8 \\
1\end{array}$ & $\begin{array}{l}165,32 \\
2\end{array}$ & $\begin{array}{l}0.876 \\
8\end{array}$ & $\begin{array}{l}166,20 \\
4\end{array}$ & $\begin{array}{l}3,78 \\
3\end{array}$ & $\begin{array}{l}163,70 \\
5\end{array}$ & $\begin{array}{l}0.29 \\
9\end{array}$ & $\begin{array}{l}258,36 \\
7\end{array}$ \\
\hline
\end{tabular}

From Table 3 it is obvious that the main emission sources for both methods were fuel combustion which occurred at turbines, compressors, and engines. Based on API Compendium method, fuel combustion contributes $97.15 \%$ to the total GHG emission, while by using IPCC method, fuel combustion contributes $63.88 \%$ to the total GHG emission. It can be understand since oil and gas production requires huge amount of energy in the form of electric power and that electric power is self-generated mainly by gas turbine generator. Compressors are used to deliver export gas to buyer thru hundreds kilo meter of pipeline that require huge amount of energy also. Both of them consume fuel which combusted to generate the energy. The estimated GHG emission from fuel combustion by using API Compendium and IPCC method was not much different i.e. 161,473 and 163,361 ton $\mathrm{CO}_{2}$ e respectively. This result indicates that the GHG emission source from fuel combustion is well identified and the Tier-1 IPCC default emission factor for fuel combustion is suitable to be used in this case.

API Compendium method estimates GHG emission from gas flaring is higher than fugitive which is in opposite with the result of IPCC method. In oil and gas operations, the amount of gas flaring is one of environmental indicator, so that the source is well identified and field-based measurement system is available, whereas the vented gas is usually not measured resulting not representative estimation result. As shown by the result presented in Table 3, the total GHG inventory calculated by IPCC method is 258,367 ton $\mathrm{CO}_{2}$ e which is $55 \%$ higher than calculated by API Compendium method $\left(166,204\right.$ ton $\left.\mathrm{CO}_{2} \mathrm{e}\right)$. The highest contributor for this differences is the GHG emission from fugitive source in natural gas production. There are two possible causes of this significant differences: 1) the fugitive emission estimated by company does not cover all the sources and 2) the default emission factor by IPCC method is just exaggerated and not suitable to be apply in this case. The quantity and composition of the fugitive emissions is generally subject to significant uncertainty. This is due to the limited capability of measurement system and when the measurement systems are available, the typical inability of these to cover the wide range of flows and variations in composition that may occur.

IPCC method estimate fugitive emission higher than flaring. As can be seen in Table 2, the average default emission factor for the fugitive emission from natural gas production (IPCC code 1.B.2.b.i) is much higher than others. The Tier-1 IPCC method uses a very wide range of emission factor for fugitive emission with level of uncertainty in the range of $-40 \%$ to $+1000 \%$ [25], so that the selection of emission factor within this range would give 
significant impact to the result of calculated GHG. The IPCC method did not fully consider the actual production situation (production way, advancement and development of technology etc.) resulting in an overestimate of fugitive emission. This result is in agreement with Chen et al., [15] which conduct the similar study for O\&G industry in China region that found the estimates of $\mathrm{CH}_{4}$ and $\mathrm{CO}_{2}$ calculated by the IPCC Tier 1 method were about 10times and 51-times higher than that of corresponding $\mathrm{CH}_{4}$ and $\mathrm{CO}_{2}$ calculated by fieldmeasurement method, respectively. The issue of using IPCC emission factor causing higher uncertainty has also raised by Bradbury et al. [26]

\section{Conclusion and Recommendation}

Oil and gas industry has their own GHG estimation method, namely API Compendium, which is different with IPCC method that used to report national GHG emission thru NDC. This study found that the estimated GHG by using IPCC method would be higher than the GHG estimated by API Compendium. The main contributor of this difference is gas venting source. Both of methods provide a quite similar estimation for GHG emission from fuel combustion sources and confirm that fuel combustion as the biggest contributor to the GHG emission in oil and gas production operations.

The GHG emission sources from fuel combustion and flaring have been well identified by O\&G company, but the inventory of GHG emission from venting and fugitive need to be improved. National emission factors database for O\&G industry segment is highly suggested to be developed.

\section{Acknowledgement}

The First author would like to express gratitude as this work is supported by EEA Program from one of $\mathrm{O} \& \mathrm{G}$ company in Indonesia.

\section{References}

1. E. D. Enger and B. F. Smith, Environmental Science, A Study of Interrelationships, 12th ed., The McGraw-Hill Companies, New York, USA (2010)

2. IPCC, Climate change 2013, The Physical Science Basis, (2013)

3. IPCC, Climate Change 2014: Synthesis Report, Intergov. Panel Clim. Chang., 169, (2014)

4. S. Amjad, R. Rudramoorthy, S. Neelakrishnan, Transp. Res. Part D Transp. Environ., 16, 3, 265-269, (2011)

5. H. Rodhe, Science., 248, 1983, 1217-1219, (1990).

6. D. T. Shindell, G. Faluvegi, D. M. Koch, G. Schmidt, N. Unger, and S. E. Bauer, Interactions, 326, 716-718, (2009)

7. EPA (Environmental Protection Agency), Global Anthropogenic Non-CO2 Greenhouse Gas Emissions: 1990 - 2030, (2012)

8. API, Compendium of greenhouse gas emissions methodologies for the oil and gas industry, 2004, (2009)

9. $\quad$ EPA (Environmental Protection Agency), Global Mitigation of Non-CO2

Greenhouse Gases: 2010-2030, (2013) 
10. Ministry of Environment and Forestry Republic of Indonesia, Indonesia Third National Communication Under UNFCCC, (2017)

11. K. Ritter, M. Lev-On, and T. Shires, Development of a consistent methodology for estimating greenhouse gas emissions from oil and gas industry operations, (2002)

12. A. Goldenberg, Accounting for greenhouse gas emissions, Master's Degree Project, University of Calgary, (2004)

13. D. T. Allen and et al., Proc. Natl. Acad. Sci., 110, 44, 18023, (2013)

14. U. Ibemere and B. Mmata, Soc. Pet. Eng., (2015)

15. G. Chen et al., Sci. Total Environ., 574, 707-715, (2017)

16. G. R. Timilsina, A. Naini, and T. Walden, Inst. Sustain. Energy, Environ. Econ., 7, (2006)

17. M. R. Johnson and A. R. Coderre, J. Air Waste Manag. Assoc., 61, 2, 190-200, (2011)

18. B. S. M. C. Borba et al., Energy Policy, 49, 430-441 (2012)

19. K. Konschnik and S. M. Jordaan, Clim. Policy, 3062, 1-19 (2018)

20. C. Dianita, A. H. Saputra, and M. B. P. Almagistra, IOP Conf. Ser. Earth Environ. Sci., 105, (2018)

21. A. Burnham, J. Han, C. E. Clark, M. Wang, J. B. Dunn, and I. Palou-Rivera, Environ. Sci. Technol., 46, 2, 619-27, (2012)

22. SKK MIGAS, Memastikan keberlanjutan, (2016)

23. Intergovernmental Panel on Climate Change, 2007: Synthesis Report IPCC, (2007)

24. IPIECA, Petroleum industry guidelines for reporting greenhouse gas emissions, (2011)

25. IPCC, 2006 IPCC Guidelines for National Greenhouse Gas Inventories, (2006)

26. M. Bradbury, A. S. Obeter, L. Drauker, W. Wang, World Resour. Inst., 23, 1-60, (2013). 